\title{
Physical therapy in infants and preschool children with burns: retrospective descriptive study
}

\author{
Mikelini Ayumi Takino', Edna Yukimi Itakussu², Celita Salmaso Trelha3 ${ }^{3}$ Paola Janeiro Valenciano 4 , \\ Dirce Shizuko Fujisawa ${ }^{5}$
}

\begin{abstract}
Introduction: Burns are traumatic injuries that occur due to external events, and particularities of pediatric patients make it more serious condition. Physical therapy is essential to the recovery of children victims of burns and it should be started early during hospitalization. Objective: Define initial and final physical therapy care in children victims of burns, during the period of hospitalization, in a Burn Treatment Centers (BTC). Methods: Retrospective and descriptive study by means of gathering information in medical records of children victims of burns, convenience sample, consisted of patients in the 0-6 age group, that were interned in BTC of University Hospital/ UEL, from January 2011 to February 2014. Results: Data from 102 medical records were collected, physical therapy was realized in 94 (92.1\%) cases, being respiratory physical therapy, placements, motor physical therapy, orthosis indication and orientation. In the first, second, last but one and last sessions, the most used breathing techniques were clearence maneuvers; the general placements was the most used; during motor physical therapy, the gait /walking and orientation were used with more frequency in last assistance. Conclusion: The initial physical therapy emphasizes the clearence maneuvers for prevention and treatment of respiratory complications that threaten the survival of the patient. The activities focused on functionality were adressed throughout the hospital stay, especially in the final stage. The physical therapy sessions progressed from passive techniques to active, according to the evolution of patients. Keywords: Burns; Child; Physical Therapy Speciality.
\end{abstract}

\section{INTRODUCTION}

Burns are traumatic injuries, occurring as a result of external events and constitute a serious public health problem worldwide, especially in low- and middle-income countries, where there is a higher percentage of mortality, especially in individuals under four years of age. ${ }^{(1)}$ Accidents can be caused by the contact with overheated liquids, fire and overheated surfaces, the inhalation of smoke, the contact with acids or corrosive substances, and electric or radioactive burns. ${ }^{(2)}$ Burns can generate functional disabilities and discrimination, with personal, social and economic consequences difficult to estimate, but certainly relevant. ${ }^{(3,4)}$

Regarding the classification, burns can be classified as first-degree, when the lesion is restricted to the epidermis and does not cause hemodynamic changes; second-degree, which affects both the epidermis and the dermis, requiring more time for healing; third-degree, when there is involvement of all layers of the skin, reaching the subcutaneous tissue and even muscular structures and bone tissue..$^{(5)}$ The identification of the depth of the lesion directly influences the prognosis, as well as the extent of the burn estimated by the calculation of the Burned Surface Area (BSA). ${ }^{(6)}$ Lund-Browder diagram is the way more accurate and used to calculate the BSA, because it considers the variations of the corporal proportions according to the age group. ${ }^{(5)}$

The particularities of the pediatric patient make the clinical setting more severe. ${ }^{(7)}$ Differently from the adult, the child has different physiological, anatomical and psychological characteristics in each age group, which will influence the choice of the most effective treatment and the prognosis. Among the differences that interfere in the treatment and prognosis are the unstable or variable peripheral circulation and the greater disposition to the edema, which implies in the need of more attention on the positioning in the bed and the early mobilization, facilitating the blood circulation and the venous return; The body surface greater than the adult in relation to mass, so when comparing the same burn in both children and adults, the representation of the total surface will be larger in the child's body; finally, the importance of the 
interaction between the professional and the child and the playful approach is emphasized, since depending on the age range, the child may not understand the therapist's commands, so the therapeutic play will contribute to the execution of the exercises in an active way. ${ }^{(8)}$ Thus, the care of the child suffering from burn injuries should take into account their peculiarities, since functional damages can be increased and the possibility of survival decreased, worsening the prognosis. Therefore, it is essential the performance of the interdisciplinary team with common tasks and objectives in the treatment of the pediatric patient, thus reducing the sequelae and possible complications caused by the injury..$^{(9)}$

Burn patient are submitted to several procedures when admitted to a hospital, being the most frequent ones, the dressing change, debridement and the skin graft. ${ }^{(10)}$ Also, during the hospitalization period, physical therapy is essential, since the acute phase of thermal injury, in order to avoid or minimize sequelae, until the phase after hospital discharge. (11) Physical therapy has as main objective the return of the functionality, acting through the prevention and reduction of sequels, which is fundamental in the rehabilitation of the pediatric patient, due to its rapid physical and motor development. ${ }^{(12,13)}$ In this sense, referral services, such as the Burn Treatment Centers (BTC), have a structure and multiprofessional team specialized for patient care, adult or pediatric, and the physical therapist is essential to recovery. However, Lima et al. ${ }^{(14)}$ emphasize the need for more research involving physical therapy in pediatric patients with burns, which include their performance from objectives to the behaviors and resources used. Most of the studies only mention some interventions in a segmented way, but do not explore in a global way in a hospital environment, information that could be valid in choosing the best techniques. Therefore, identifying the physical therapy approach in the care of the children at BTC makes it possible to establish the relationship between the child's needs in relation to the burn and their peculiarities (objectives) together with the appropriate and indicated procedures/techniques for recovery.

Thus, the present study has the proposal to characterize the initial and final physical therapy care in children with burn injuries, during the period of hospitalization in a Burn Treatment Centers (BTC), since its results may serve as a basis for discussion and assistance in the selection of techniques to be used in the pediatric population. Still, the selection of adequate techniques in the care of the child with burns during the period of hospitalization will reflect a greater possibility of recovery, survival and functionality, therefore in a better quality of life, since it is a crucial moment of the treatment.

\section{METHODS}

A retrospective descriptive study was carried out through the collection of information in the medical records of pediatric with burn injuries. The study was performed using a convenience sample of all patients in the age group between zero and six years, who were hospitalized in the BTC of the University Hospital of Londrina State University (UH/UEL), from January/2011 to February/2014. The study is part of the research project "Physical-functional evaluation of burn victims", approved by the Research Ethics Committee involving Human Beings of the UEL (N. 138/2013).

The Statistical service of the University Hospital was consulted to obtain the record of all patients who were admitted at BTC/HU/UEL. A total of 107 pediatric patients admitted to the BTC/UH/UEL were identified, due to the nonlocation of medical records and incomplete information the data collection was performed in 102 medical records.

To collect the data, was used a pre-elaborated form containing topics related to the children, burn and treatments: gender, age, city of birth, depth and severity of the lesion, percentage of BSA (BSA\%), etiological agent and cause of the lesion, total time stayed in the ward and in the Intensive Care Unit (ICU), need to debridement, grafts, scarotomy and amputations, presence of airway burn, outcome of hospitalization (discharge or death), physical therapy, and number of physical therapy treatment sessions. For the characterization of the physical therapy care, data were collected regarding the place of care (ICU or ward), need to Mechanical Pulmonary Ventilation (MPV), Tracheostomy, Noninvasive ventilation (NIV) and to the conducts performed in the first, second, last but one and last sessions, such as respiratory physical therapy, positioning, motor physical therapy, functional activities, orthosis indication and orientation. It is worth mentioning that the conduct was described according to the form and terms used in the medical records.

The collected data were organized and inserted in spreadsheets in the Microsoft ${ }^{\circledR}$ Excel 2010 software. Statistical analysis was performed using the Software Statistical Package for the Social Sciences (20.0) software. The normality of data distribution was analyzed using the Shapiro-Wilk test. Variables such as age, BSA percentage, days of hospitalization, total days in ICU and ward are presented in median with their respective interquartile ranges [25-75]\% and the other data are in absolute and relative frequency, the significance established in $\mathrm{P}<0.05$. Correlations were assessed by the Spearman's Correlation Coefficient with a confidence interval of $95 \%$.

\section{RESULTS}

Data were collected in 102 medical records of the children with burn in the BTC/HU/UEL, with the median age of 2.0 [1.0-4.0] years, $34.0(33.3 \%)$ female and $68.0(66.6 \%)$ male, the BSA\% of $7.7[4.0-13.3] \%$. All accidents occurred in a domestic environment, and $73.53 \%$ of the children presented burn caused by hot liquids; $14.7 \%$ by contact with fire; $7.85 \%$ by contact with superheated surface; $0.98 \%$ by the contact with chemical substance; $0.98 \%$ by electrical burn; and 
$1.96 \%$ was not described in the medical record. In relation to severity, most of them (75.4\%) were classified as major burn and of the total analyzed, $67.6 \%$ of the children presented multiple body regions burned; besides, $64.7 \%$ of them needed debridement; $47.0 \%$ needed graft; $1.9 \%$ needed escharotomy and $0.9 \%$ needed de amputation. The hospitalization period was 11.0 [5.0-15.0] days, and $19.6 \%$ needed assistance in the ICU and an individual died (Table 1).

During the hospitalization period, 94 (92.1\%) performed physical therapy, and 59 (62.7\%) children received one care per day, $34(36.1 \%)$ received more than one daily care and only one child $(1.0 \%)$ the data were not included in the medical records. Regarding the total number of children who underwent physical therapy, 76 (80.8\%) were in the ward and $18(19.1 \%)$ in the ICU in the first care; 89 (87.2\%) children received a second care, wherein, 75 (84.2\%) were in the ward and $14(15.7 \%)$ in the ICU; 79 (84.0\%) received physical therapy in the last but one session, of these, 77 (97.4\%) were

TABLE 1. Characterization of children with burns during the hospitalization period

\begin{tabular}{|c|c|}
\hline Variables & Children ( $\mathrm{N}=102)$ \\
\hline BSA (\%), median [25-75\%] & $7.7[4.0-13.3]$ \\
\hline BSA (\%) not reported & $2(1.9)$ \\
\hline Major burn, No. (\%) & $77(75.4)$ \\
\hline Medium burn, No. (\%) & $21(20.5)$ \\
\hline Severity not reported, No. (\%) & $4(3.9)$ \\
\hline Second degree burn, No. (\%) & $71(69.6)$ \\
\hline Third degree burn, No. (\%) & $26(25.4)$ \\
\hline Depth not reported, No. (\%) & $5(4.9)$ \\
\hline Home environment, No. (\%) & $102(100.0)$ \\
\hline Face and/or cervical burn, No.(\%) & $5(4.9)$ \\
\hline Trunk burn, No. (\%) & $3(2.9)$ \\
\hline UL burn, No.(\%) & $14(13.7)$ \\
\hline LL burn, No.(\%) & $10(9.8)$ \\
\hline Multiples areas, No. (\%) & $69(67.6)$ \\
\hline Area not reported, No. (\%) & $1(0.9)$ \\
\hline Total hospitalization time (days), median [25-75\%] & $11[5.0-15.0]$ \\
\hline ICU, No.(\%) & $20(19.6)$ \\
\hline Period in ICU (days), median [25-75\%] & $3[2.0-8.5]$ \\
\hline Period in Ward (days), median [25-75\%] & $10[5.0-14.0]$ \\
\hline Debridement, No.(\%) & $66(64.7)$ \\
\hline Escarotomy, No.(\%) & $2(1.9)$ \\
\hline Graft, No.(\%) & $48(47.0)$ \\
\hline Amputation, No. (\%) & $1(0.9)$ \\
\hline Airway Burn, No.(\%) & $1(0.9)$ \\
\hline Deaths, No.(\%) & $1(0.9)$ \\
\hline
\end{tabular}

Abbreviations: BSA = burned surface area; UL = Upper Limbs; $L L=$ Lower Limbs; ICU = Intensive Care Unit; No = number. in ward and 2 (2.5\%) in the ICU; 92 (97.8\%) received physical therapy in the last session, of these, 90 (97.8\%) were in ward and $2(2.1 \%)$ in the ICU.

The sessions consisted of respiratory physical therapy, placements, motor physical therapy, orthosis indication and orientations. During the first, second, last but one and last sessions the most used breathing techniques were clearence maneuvers. In relation to the positioning, the global was the most used. During physical therapy, described as motor, were used more frequently the passive exercises, stretching and motor kinesiotherapy, this term is as identified in the medical records. The orthoses were little used and the orientations were more frequent in the last session (Table 2).

The moderate correlation occurred between the grafting procedure and the number of physical therapy treatment sessions $(r=0.47 ; P<0.001)$, being that the children who needed grafting had a greater number of sessions. The grafting procedure was also moderately correlated with length of hospital stay ( $r=0.65 ; P<0.001)$, the children who performed the procedure remained hospitalized more time.

It was observed a moderate correlation $(r=0.47 ; P<0.001)$ between the BSA and the physical therapy, the higher the BSA, the greater the number of daily treatment sessions. There was also a moderate correlation between BSA and physical therapy time $(r=0.60 ; \mathrm{P}<0.001)$; and a moderate correlation between BSA and the total amount of physical therapy care during the hospitalization period $(r=0.61 ; P<0.001)$, as shown in the figure 1.

\section{DISCUSSION}

The practice of evidence-based physical therapy is essential for the valorization of the profession, since it is characterized by effective and quality care, lower cost of treatment and, consequently, greater patient satisfaction. ${ }^{(15)}$ It is known that after burn accidents in which hospitalization is necessary, physical therapy is essential from the first day, in order to avoid or minimize possible sequelae, to the rehabilitation phase and after discharge. ${ }^{(11)}$ The present study analyzed the physical therapy records of all medical records of the children with burns, zero to six years, attended in the BTC/UH/UEL from January/2011 to February/2014. Because it is a reference in the treatment of burn, they have physical therapy for all patients, except for those who for some reason (death, transfer, discharge of the sector) remain hospitalized only at night.

According to other studies ${ }^{(16,17,18)}$ there was a higher prevalence of burn injuries in males, where the place of occurrence was the home environment and the main cause of the scaling. Fernandes et al. ${ }^{(19)}$ and Pedro et al. ${ }^{(20)}$ suggest as possible explanation the greater disposition of the boys for risk games and, consequently, greater exposure to the causal agents of the burn. Added to it, Vendrusculo et al. ${ }^{(21)}$ explore the domestic environment, especially the kitchen, as a frequent place for accidents involving children and most 
TABLE 2. Characterization of physical therapy care during the hospitalization period

\begin{tabular}{|c|c|c|c|c|c|}
\hline & \multirow{2}{*}{ Cares: } & 19 & 29 & Last but one & Last \\
\hline & & $\mathrm{N}=94$ & $\mathrm{~N}=89$ & $\mathrm{~N}=75$ & $\mathrm{~N}=92$ \\
\hline & Clearence maneuvers, No. (\%) & $28(29.7)$ & $27(30.3)$ & $15(20.0)$ & $11(11.9)$ \\
\hline & Re-expansion maneuvers, No. (\%) & $12(12.7)$ & $13(14.6)$ & $11(14.6)$ & $6(6.5)$ \\
\hline & Reduce hyperinsuflation maneveurs, No. (\%) & $1(1.0)$ & $1(1.1)$ & 0 & $1(1.0)$ \\
\hline & Cough Stimulation, No. (\%) & 15 (15.9) & $11(12.3)$ & $4(5.3)$ & $5(5.4)$ \\
\hline $\begin{array}{c}\text { Respiratory } \\
\text { Physical therapy }\end{array}$ & Thoraco-abdominal Rebalance, No. (\%) & $2(2.1)$ & $1(1.1)$ & $1(1.3)$ & $1(1.0)$ \\
\hline & Adjustments of MPV, No. (\%) & $4(4.2)$ & $4(4.4)$ & $1(1.3)$ & $1(1.0)$ \\
\hline & Adjustments of NIV, No. (\%) & $1(1.0)$ & 0 & 0 & 0 \\
\hline & Global Positioning, No. (\%) & $29(30.8)$ & $34(38.2)$ & $12(13.4)$ & $5(5.4)$ \\
\hline & Segmental Positioning, No. (\%) & $6(6.3)$ & $3(3.3)$ & $2(2.6)$ & $3(3.2)$ \\
\hline & Motor kinesiotherapy, №. (\%) & $25(26.5)$ & $19(21.3)$ & $13(17.3)$ & $20(21.7)$ \\
\hline & Passive, No. (\%) & $32(34.0)$ & $34(38.2)$ & $21(28.5)$ & $26(28.2)$ \\
\hline & Active-assisted, No. (\%) & $2(2.1)$ & $2(2.2)$ & $3(4.0)$ & $2(2.1)$ \\
\hline & Active-free, No. (\%) & $7(7.4)$ & $11(12.3)$ & $11(14.6)$ & $22(3.9)$ \\
\hline Motor physical & Stretching, No. (\%) & $21(22.3)$ & $22(24.7)$ & $22(29.3)$ & $23(25.0)$ \\
\hline therapy & Orthostatism, No. (\%) & $4(4.2)$ & $10(1.1)$ & $15(20.0)$ & $13(14.1)$ \\
\hline & Gait, No. (\%) & $5(5.3)$ & $12(13.4)$ & $25(33.3)$ & $30(32.6)$ \\
\hline & Playful Activity, No. (\%) & $5(5.3)$ & $7(7.8)$ & $15(20.0)$ & $23(25.0)$ \\
\hline & Orthoses, No. (\%) & $1(1.0)$ & 0 & $2(2.6)$ & $2(2.1)$ \\
\hline & Orientation, No. (\%) & $8(8.5)$ & $13(14.6)$ & $15(20.0)$ & $31(33.6)$ \\
\hline
\end{tabular}

Abbreviations: MPV = Mechanical Pulmonary Ventilation; NIV = Non-Invasive Ventilation; No=number.

A

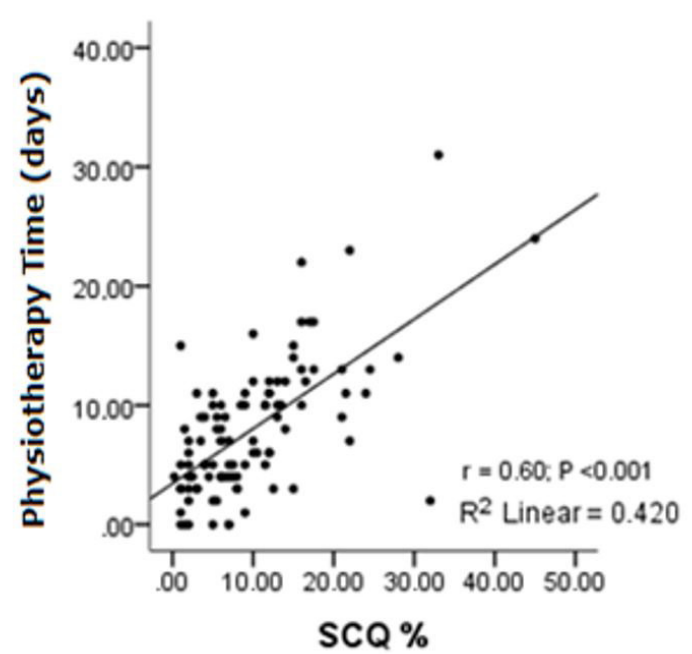

B

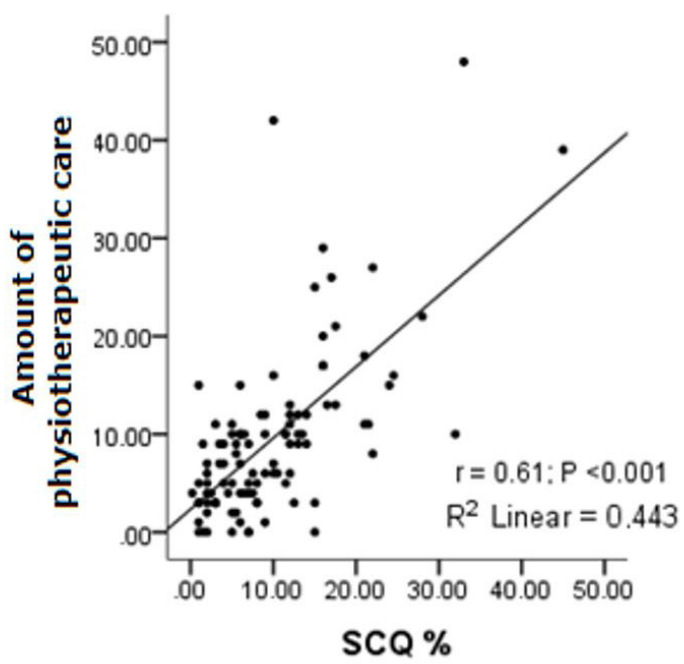

FIGURE 1 - Scatter plot of variables analyzed using Spearman's Correlation Coefficient (rS). Note: A - Positive correlation between BSA versus Physical therapy time in days. B - Positive correlation between BSA percentage versus amount of physical therapy care.

injuries occur in this place, often due to the absence or inattention of the person responsible for the child. In relation to the affected body region, studies show that the upper limbs and trunk are frequently affected in the patients with burn in hospitalization. ${ }^{(22,23)}$ In our study, there was a higher frequency in the involvement of multiple regions, which may be due to the characteristics of the lesion mechanism. Considering that scalding was more frequent, the superheated liquid spilled on small children would involve more than a bodily region. On the other hand, burns by contact with superheated surface for 
example, would only involve a region. In addition, although the BSA median is $7.7 \%$, most of the burns are characterized by the multiple regions involved, lesions of $2 \mathrm{nd}$ and/or $3 \mathrm{rd}$ degree, and classification of major burn.

In the present study, the grafting performed moderately correlated with both the longer hospitalization time and the greater number of physical therapy treatment sessions, which may be explained by the need for greater attention and care after the procedure. In this sense, Millan et al. ${ }^{(10)}$ emphasize that the need for hospitalization and surgical procedures in the pediatric burned patient reflects in greater morbidity and the possibility of developing with sequelae. There was also a moderate correlation between the BSA and the time and total amount of physical therapy care during hospitalization, which indicates when the larger the burned area the greater the need for physical therapy. Samuel et al..$^{(24)}$ in a study with hospitalized patients with burn in a tertiary hospital in Malawi (Africa), observing a high proportion of procedures and complications such as amputations and contractures, respectively, highlighted the need for physical therapy for the prevention of sequelae and a better quality of life in the long term.

Regarding the physical therapy care, the patients received the frequency of once or more per day, depending on the need. Burn victims often present a reduction in their overall activity, or even manage to maintain them, but present a restriction or reduction of movement of the burned region due to pain and bandages. ${ }^{(25)}$ Thus, early care keeps the patient active, aiming for greater functional independence and reduction of the period of hospitalization, in addition to preparing him/her to return to his normal activities of daily living after discharge. ${ }^{(11)}$

Physical therapy also approaches the pneumofunctional aspects, especially when there is an inhalation injury, in order to reverse or to minimize possible complications resulting from the post-traumatic process. ${ }^{(26)}$ The respiratory approach aims to maintain airway permeability, assist respiratory mechanics and improve pulmonary volumes and capacities. ${ }^{(27)}$ In case of need for mechanical ventilation, it is up to the physical therapist to intervene in the regularization of ventilatory parameters, contributing to a better clinical evolution. ${ }^{(28,29)}$ In the present study, the most commonly used respiratory techniques were clearence maneuvers, followed by re-expansive maneuvers, cough stimulation, and the less common one used was the reduce hyperinsuflation maneveurs, thoraco-abdominal rebalance, and adjustments in MPV and NIV; all with higher frequency in the first days of hospitalization, reducing the frequency when close to hospital discharge, which indicates an improvement in the respiratory.

In relation to the positioning of vicious postures, the literature indicates that motor sequelae of patients who are victims of burns are often associated with antalgic posture, usually with flexion retraction. ${ }^{(30)}$ The adequate positioning of the patient should be worked with the objective of preventing motor sequelae and improving pulmonary ventilation, avoiding the development of secondary affections. ${ }^{(31)}$ In this study, both global and specific positioning were identified, being global the most frequent and both were performed mainly in the first days of hospitalization, which may be due to the gradual increase in global activity, for example gait or even the orientations of the positions to the child/family, for them to perform independently of the therapist.

As regards the motor aspect, the shortening of the tissue can result in loss of skin elasticity and joint range of motion or deviations of posture. ${ }^{(32)}$ Santana, Brito and Costa ${ }^{(12)}$ reported benefits in relation to the gain of range of motion in patients with burn submitted to physical therapy. It is known that increased flexibility should be approaches in the treatment program of the patient, since there is loss of skin elasticity, depending on the depth, which can lead to restriction of movement, and even functional disability. ${ }^{(33)}$ The concern about maintaining flexibility occurred, since passive exercises, stretching and motor kinesiotherapy were present in both initial treatment and close to hospital discharge. It is worth mentioning that the description of active-assisted and/or active-free exercises were also verified, but less frequently what may be due to preference for the use of the more generic term: motor kinesiotherapy.

Orthostatism, gait and playful activities were performed more in the days before the discharge, which probably occurred due to the clinical improvement of the children; but they were used in the first days of hospitalization in some cases. Among the many benefits, early ambulation provides to the patient the opportunity to maintain social contact, in addition to preventing possible functional impairments. ${ }^{(34)}$ Besides that, Santos and Ferreira ${ }^{(35)}$ in their study with children submitted to physical therapy pointed out the contributions of the care from the point of view of them and observed that they relate the play in the hospital with the physical therapy in the moment that associate the playful and the imagination to the treatment. The playful resources and the interaction of the child with the team promote a better evolution of the clinical condition of the patient, reducing the stress resulting from hospitalization and favoring the adherence to the clinical procedures performed. ${ }^{(36)}$ In physical therapy, playful activity is fundamental in the care of the pediatric patient, since it helps them to achieve the therapeutic objectives and make the therapy pleasurable. ${ }^{(37)}$

Finally, the orientation of positioning and simple exercises to perform at home, orthosis indication or even referral for outpatient follow-up are also part of the role of physical therapy. ${ }^{(11)}$ Similarly, these aspects were incorporated into the physical therapy care, orthosis indication were made when necessary and the orientations were most frequently performed in the last session in which any aspect that needs to be considered after hospital discharge should be reinforced. 
The limitations of the study are due to the collection of data in the medical records and the convenience sample, and it is recommended the development of randomized clinical trials to prove the efficacy of physical therapy in children who are victims of burns, whether in the hospital stay or in the outpatient phase.

\section{CONCLUSION}

Burns were more frequent in children with two years of age and predominance in boys, being mostly caused by hot liquids and occurred in the home environment. The majority of the children were classified as having large burns and had multiple regions of the body involved, and it was necessary to perform surgical procedures with hospitalization time around 11 days.

Regarding physical therapy, during the period of hospitalization in a BTC for infants and children suffering from burns, it was observed that the initial care was directed at the prevention and treatment of respiratory complications. In this sense, clearence maneuvers occurred more frequently, when compared to the re-expansive and reduce hyperinsuflation maneveurs. The return or maintenance of the motor function was approached from the beginning to the end of the follow-up in the hospital period, being more used the global positioning, kinesiotherapy (therapeutic exercises) and functional activities. According to the evolution of the pediatric patient with burns, the physical therapy sessions are changing from more passive to active techniques. Another aspect is that the orientation were performed at the end of the hospitalization period, that is, close to hospital discharge. It was also observed the use of playful activity during the sessions. Thus, the selection of physical therapy procedures performed at the initial and final sessions indicated the need for care focused on survival and functional recovery, considering the peculiarities of the pediatric patient.

\section{AUTHOR'S CONTRIBUTION}

Dirce S. Fujisawa and Celita S. Trelha- advisors, participated in the preparation of the project, corrections, elaboration of the characterization form, organization of the data and direction of the results, contributed to the discussion and conclusion. Mikelini A. Takino and Edna Y. Itakussu - participated in the writing of the project, data collection in the medical records, data tabulation and discussion. Paola J. Valenciano - participated in the elaboration and registration of the project, corrections of text, training for collection in medical records, statistical analysis and interpretation of results, writing and submission of the article.

\section{CONFLICTS OF INTEREST}

The authors declare that they have no conflicts of interest.

\section{AUTHOR DETAILS}

${ }^{1}$ Undergraduate student of the Physical therapy course, PIBIC/CNPQ fellowship, Londrina State University (UEL), Londrina (PR), Brazil. ${ }^{2}$ Physical therapist of the University Hospital of Londrina, Londrina (PR), Brazil. ${ }^{3}$ Professor of Physical therapy, Physical therapy Department, Londrina State University (UEL), Londrina (PR), Brazil. ${ }^{5}$ Physical therapist and Professor of the Physical therapy Department, fellowship in research productivity/Fundação Araucária, Londrina State University (UEL), Londrina (PR), Brazil.

\section{REFERENCES}

1. Mock C, Peck M, Peden M, Krug E, eds. A WHO plan for burn prevention and care. World Health Organization. [serial on the internet] 2008 [cited 2008]. Avaiable from: URL: http://whqlibdoc.who.int/ publications/2008/9789241596299_eng.pdf.

2. Forjuoh SN. Burns in low- and middle-income countries: A review of available literature on descriptive epidemiology, risk factors, treatment, and prevention. Burns. 2006;32(5):529-537.

3. Albuquerque MLL, Silva GPF, Diniz DMSM, Figueiredo AMF, Câmara TMS, Bastos VPD. Análise dos pacientes queimados com sequelas motoras em um hospital de referência na cidade de Fortaleza-CE. Rev Bras Queimaduras. 2010;9(3):89-94.

4. Laporti GA, Leonardi DF. Post-traumatic stress disorder in burn-injured patients. Rev Bras Queimaduras. 2010;9(3):105-14.

5. Vale ECS. Primeiro atendimento em queimaduras: a abordagem do dermatologista. An Bras Dermatol. 2005;80(1):9-19.

6. Serra MCVF, Gomes DR, Crisóstomo MR. Cálculo da área queimada e indicadores para internação hospitalar. In: Maciel E, Serra MC. Tratado de queimaduras. São Paulo: Editora Atheneu; 2006. p. 43-50.

7. Serra, MCVF, Lemos T, Costa DM. Peculiaridades do Tratamento Inicial da Criança Queimada. In: Lima Júnior EM, et al. Tratado de queimaduras no paciente agudo. 2.ed. São Paulo: Editora Atheneu; 2008. p. 49-52.

8. Lima VCS. Abordagem fisioterapêutica da criança queimada. In: Maciel E, Serra MC. Tratado de queimaduras. São Paulo: Editora Atheneu, 2006. p. $235-240$

9. Herdon DN, Barret JP. Organização do tratamento da queimadura. In: Herdon DN, Barret JP. Tratamento das queimaduras. Rio de Janeiro: Editora Dilivros, 2002. p. 27-32.

10. Millan LS, Gemperli R, Tovo FM, Mendaçolli TJ, Gomez DS, Ferreira MC. Epidemiological study of burns in children treated at a tertiary hospital in São Paulo. Rev Bras Cir Plást. 2012;27(4):611-5.

11. Serghiou M, Cowan A, Whitehead C. Rehabilitation After a Burn Injury. Clin Plast Surg. 2009;36(4):675-86.

12. Santana CML, Brito CF, Costa ACSM. Importance of physical therapy in the rehabilitation of the burned patient. Rev Bras Queimaduras. 2012;11(4):240-5.

13. Gawryszewski VP, Bernal RTI, Silva NN, Neto OLM, Silva MMA, Mascarenhas MDM, et al. Public hospital emergency department visits due to burns in Brazil, 2009. Cad. Saúde Pública. 2012;28(4):629-640.

14. Lima CTS, Ribeiro LD, Teles MD, Falcão GL, Campos NG. Atuação da Fisioterapia em Pacientes Pediátricos Vítimas de Queimaduras: Revisão Sistemática. Rev Fisioter S Fun. 2013;2(1):50-61.

15. Shiwa SR, Costa LOP, Moser ADL, Aguiar IC, de Oliveira LVF. PEDro: the physical therapy evidence database. Fisioter Mov. 2011;24(3):523-33.

16. Aragão JA, Aragão MECS, Filgueira DM, Teixeira RMP, Reis FP. Epidemiologic study of burn injuries in children admitted to the Burn Unit of the Hospital de Urgência de Sergipe. Rev Bras Cir Plást. 2012;27(3):379-82

17. Santos TP, Sá SMP. Ocorrência De Queimaduras Em Crianças Em Um Centro De Referência. Revista Baiana de Saúde Pública. 2014;38(3):524-538.

18. Rocha Neta AP, Maciel SM, Lopez MLH, Sardinha AHL, Cunha CLF. Burn Accident Profile In Children Under The Age Of Ten Years. SANARE. 2014;13(1):41-47.

19. Fernandes FMFA, Torquato IMB, Dantas MAS, Pontes Júnior FAC, Ferreira JA, Collet N. Queimaduras em crianças e adolescentes: caracterização clínica e epidemiológica. Rev Gaúcha Enferm. 2012;33(4):133-141.

20. Pedro ICS, Rinaldi ML, Pan R, Gonçalves N, Rossi LA, Farina Junior JÁ, Nascimento LC. Hospitalization profile for acute treatment of burned children and adolescents, 2005-2010. Rev Bras Queimaduras. 2014;13(3):154-60.

21. Vendrusculo TM, Balieiro CRB, Echevarría-Guanilo ME, Farina JA Jr, Rossi LA. Queimaduras em ambiente doméstico: características e circunstâncias do acidente. Rev. Latino-Am. Enfermagem. 2010;18(3):157-164. 
22. Montes SF, Barbosa MH, Sousa Neto AL. Clinical and epidemiological aspects of burned patients Hospitalized in a teaching hospital. Rev Esc Enferm USP. 2011;45(2):369-73.

23. Martins CBG, Andrade SM. Burns in children and adolescents: hospital morbidity and mortality analysis. Acta Paul Enferm 2007;20(4):464-9.

24. Samuel JC, Campbell ELP, Mjuweni S, Muyco AP, Cairns BA, Charles AG. The Epidemiology, Management, Outcomes and Areas for Improvement of Burn Care in Central Malawi: an Observational Study. J Int Med Res. 2011;39(3):873-879.

25. Schneider JC, Holavanahalli R, Helm P, Goldstein R, Kowalske K. Contractures in Burn Injury: Defining the Problem. Journal of Burn Care \& Research. 2006;27(4):508-514.

26. Suman OE, Mlcak RP, Herndon DN. Effect of exercise training on pulmonary function in children with thermal injury. J Burn Care Rehabil. 2002;23(4):288-93.

27. Lima ALJ, Monteiro PVM, Iwabe C. Respiratory System Repercussions And Physical therapy. Revista Multidisciplinar de Saúde. 2011;3(6):48-60.

28. Faustino EA. Concepts and Monitoring of Pulmonary Mechanic in Patients under Ventilatory Support in Intensive Care Unit. RBTI. 2007;19(2):161-169.

29. Santos FRA, Schneider Júnior LC, Forgiarini Junior LA, Veronezi J. Effects of manual rib-cage compression versus PEEP-ZEEP maneuver on respiratory system compliance and oxygenation in patients receiving mechanical ventilation. Rev Bras Ter Intensiva. 2009;21(2):155-161.
30. Davoodi P, Fernandez JM, O SJ. Postburn sequelae in the pediatric patient: clinical presentations and treatment options. J Craniofac Surg. 2008;19(4):1047-52.

31. Civile VT, Finotti CS. Early physical therapy approach in critical burned patients. Rev Bras Queimaduras. 2012;11(2):85-8.

32. Leblebici $B$, Adam M, Bağiş S, Tarim AM, Noyan T, Akman MN, Haberal MA. Quality of life after burn injury: the impact of joint contracture. J Burn Care Res. 2006;27(6):864-8.

33. Melo SV, Linhares LD, Almeida RD. Effect of Samiball ${ }^{\circledR}$ method on the flexibility and expandability in a burns victim: case report. Rev Bras Queimaduras. 2011;10(2):71-4.

34. Rocha MS, Rocha ES, Souza JPC. Fisioterapia em queimados: uma pesquisa Bibliográficaacerca dos principais recursos fisioterapêuticos e seus benefícios. Revista Tema. 2010;9(13).

35. Santos KPB, Ferreira VS. Contributions for Physical Therapy from the Children's Point of View. Rev. Bras. Ed. 2013;19(2):211-224.

36. Azevedo DM, Santos JJS, Justino MAR, Miranda FAN, Simpson CA. O brincar enquanto instrumento terapêutico: opinião dos acompanhantes. Revista Eletrônica de Enfermagem. 2008;10(1):137-144.

37. Fujisawa DS, Manzini EJ. Professional training in physical therapy: the use of play activities in The treatment of children. Rev. Bras. Ed. Esp. 2006;12(1):65-84 